\title{
Sequencing and analysis of the Bacillus subtilis lytRABC divergon: a regulatory unit encompassing the structural genes of the $N$-acetylmuramoyl-L-alanine amidase and its modifier
}

\author{
Vladimir Lazarevic, ${ }^{1,2}$ Philippe Margot, ${ }^{1}$ BlazenKa Soldo $^{1} \dagger$ and Dimitri Karamata ${ }^{1 *}$ \\ ${ }^{1}$ Institut de génétique et de biologie microbiennes, Université de Lausanne, Rue César-Roux 19, 1005 Lausanne, \\ Switzerland \\ ${ }^{2}$ Institut za botaniku, Bioloski fakultet, Univerzitet u Beogradu, Takovska 43, 11000 Beograd, Yugoslavia
}

(Received 16 March 1992; revised 27 May 1992; accepted 3 June 1992)

\begin{abstract}
The regulatory unit of Bacillus subtilis strain 168 encompassing the structural genes of the $N$-acetylmuramoylL-alanine amidase and of its modifier has been sequenced, and found to be a divergon consisting of divergently transcribed operons $l y t A B C$ and $l y t R$. Proteins LytA, LytB and LytC are endowed with export signal peptides. Mature LytA is a $9.4 \mathrm{kDa}$, highly acidic polypeptide whose deduced amino acid sequence points to a lipoprotein. LytB and LytC, the modifier and the amidase, are highly basic. After cleavage of the signal sequence their molecular masses are 74.1 and $49.9 \mathrm{kDa}$, respectively. These two proteins share considerable homology in their $\mathrm{N}$-terminal moieties and have three GSNRY consensus motifs, characteristic of nearly all amidases. The C-terminal moiety of LytB exhibits homology to the product of spoIID. LytR is a $35 \mathrm{kDa}$ protein which acts as an attenuator of the expression of both $l y t A B C$ and $l y t R$ operons. Transcription of the $l y t A B C$ operon proceeds from two promoters: $P_{D}$, identified as $P_{28-7}$ (Gilman et al., 1984), and an upstream $P_{A}$. The former only is subject to LytR attenuation. Translational initiation of $l y t B$ and $l y t C$ is directed by UUG start codons, suggesting that $l y t A$, $B$ and $C$ undergo coupled translation. Transcription of $l y t R$ is initiated at two start sites, one of which corresponds to a highly intense $P_{A}$ promoter whereas the other does not seem to share much homology with any of the known promoter consensus sequences. Both promoters are attenuated by LytR. It is confirmed that the synthesis of the amidase is controlled at least in part by SigD, i.e. that it belongs to the fla regulon and that its activity, or part of it, is co-regulated with flagellar motility. The role of the mutations conferring the Sin, Fla and Ifm phenotypes in the expression of the lyt $A B C$ operon is discussed.
\end{abstract}

\section{Introduction}

During vegetative growth the cell wall of Bacillus subtilis, strain 168 , is endowed with two major autolysins: the $N$-acetylmuramoyl-L-alanine amidase and the endo- $\beta$ $N$-acetylglucosaminidase (Rogers et al., 1980). Both belong to a specific class of cell-wall-bound proteins (Studer \& Karamata, 1988; Margot \& Karamata, 1992), and their molecular masses, derived from SDS-PAGE

* Author for correspondence. Tel. +4121206075; fax +4121206078.

† Permanent address: Centar za geneticko inzenjerstvo i biotehnologiju, Filipa Kljajica 12, 71000 Sarajevo, Bosnia and Herzegovina.

Abbreviations: CWBP, cell-wall-bound protein; RBS, ribosomebinding site.

The nucleotide sequence data reported in this paper have been submitted to GenBank and have been assigned the accession number M87645. mobility, are about 49 and $90 \mathrm{kDa}$, respectively (Herbold \& Glaser, 1975; Rogers et al., 1984). In vitro (Herbold \& Glaser, 1975) and in vivo (Margot \& Karamata, 1992) analyses have revealed that the amidase activity is enhanced two- to threefold by another cell-wall-bound protein (CWBP), the modifier. The modifier and the amidase were mapped near $310^{\circ}$, and cloned (Margot \& Karamata, 1992). Their inactivation by insertional mutagenesis has revealed that they are encoded by genes $l y t B$ and $l y t C$, respectively. That the latter genes belong to the same operon accounts for the equimolar amounts of CWBP49 (the amidase) and CWBP76 (the modifier) in native cell wall. Other enzymes hydrolysing peptidoglycan have been described: an amidase encoded by the gene $c w l A$ (Kuroda \& Sekiguchi, 1990; Foster, 1991); and two autolysins encoded by the defective bacteriophage PBSX, which were identified as an amidase and an $N$-acetylmuramidase (Ward et al., 1982). 
The regulation of the expression of the operon encoding the amidase and the export of this protein are apparently complex since they are affected by mutations in a variety of genes. It was shown that the amidase activity is under the control of $\operatorname{sig} D(f l a B)$, the gene which encodes the $\sigma$ factor required for the expression of the flagellar regulon (Marquez et al., 1990). That mutational inactivation of sig $D$ reduces the amidase activity to about $30 \%$ of its wild-type level (Marquez $e t$ al., 1990) suggests that expression of this gene can proceed from another promoter. The regulatory role of the product of the gene $\sin$, a repressor of $a p r E$, the alkaline protease gene (Gaur et al., 1991), is more complex: disruption of $\sin (f l a D)$ is accompanied by a decrease of the amidase activity comparable to that in a sigD strain (P. Margot, unpublished), suggesting an effector role for Sin. However, more paradoxically, certain mutations in the $\sin$ gene (flaD2, for example) lead to nearly total disappearance of the amidase activity; the residual activity in the latter mutants amounts to $2.5 \%$ of that of the wild-type (Margot et al., 1991), and could be due to the other, minor, autolytic activities (see above). Finally, strains with the increased flagellar motility phenotype (Ifm) have a two- to sevenfold increased autolytic activity (Pooley \& Karamata, 1983; H. M. Pooley, unpublished). Overexpression of the amidase gene seems however to be due to at least two mutations, both located around $310^{\circ}$ between his $A$ and gtaB genes (Pooley \& Karamata, 1984).

To further our understanding of the apparently complex control mechanism of the amidase expression we have sequenced the whole regulatory unit which contains $l y t C$, the structural gene of amidase. We report that this unit is under the control of at least four promoters. It consists of two divergently transcribed operons, whose expression is under the control of a protein encoded by one of them.

Part of this contribution was presented at the 6th International Conference on Bacilli, Stanford, California, USA (July, 1991). During the preparation of the manuscript part of the sequence reported here below was published (Kuroda \& Sekiguchi, 1991).

\section{Methods}

Bacterial strains, plasmids and phage. These are listed in Table 1. Fragments from the $B$. subtilis chromosomal DNA insert in phage $\lambda 63$ (Mauël et al., 1989) were subcloned in pMTL20EC $\left(\mathrm{Ap}^{\mathrm{r}} \mathrm{Em}^{r} \mathrm{Cm}^{r}\right)$

Table 1. Bacterial strains, plasmids and bacteriophage

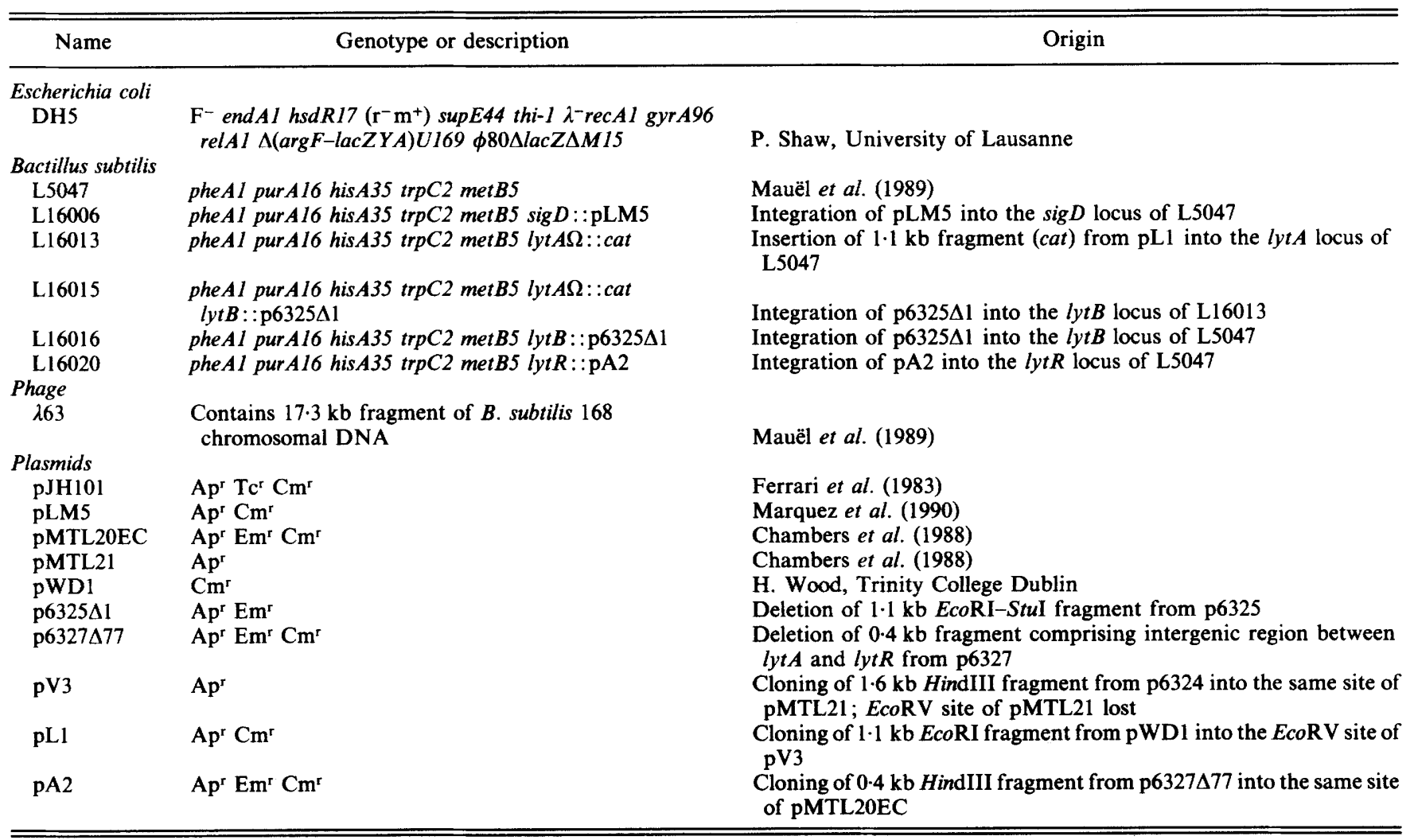


(Chambers et al., 1988) except for the insert in plasmid 6302, which was cloned in $\mathrm{pJH} 101\left(\mathrm{Ap}^{\mathrm{r}} \mathrm{Tc}^{\mathrm{r}} \mathrm{Cm}^{\mathrm{r}}\right)($ Ferrari et al., 1983) and maintained in Escherichia coli strain DH5.

Media and growth. E. coli strains were grown in LB containing selective agents: ampicillin $\left(50 \mu \mathrm{g} \mathrm{m}^{-1}\right)$, erythromycin $\left(10 \mu \mathrm{g} \mathrm{ml}^{-1}\right)$, and chloramphenicol $\left(10 \mu \mathrm{g} \mathrm{ml}^{-1}\right)$. B. subtilis strains were grown in SPIZ I, SPIZ II, SA and LB media as previously described (Karamata $\&$ Gross, 1970). When required, media were supplemented with amino acids $\left(20 \mu \mathrm{g} \mathrm{ml}^{-1}\right)$, adenine $\left(100 \mu \mathrm{g} \mathrm{ml}^{-1}\right)$, erythromycin $\left(0.25 \mu \mathrm{g} \mathrm{ml}^{-1}\right.$ or $\left.25 \mu \mathrm{g} \mathrm{ml}^{-1}\right)$ and chloramphenicol $\left(3 \mu \mathrm{g} \mathrm{ml}^{-1}\right)$.

DNA preparation. For sequencing, plasmid DNA was prepared by the alkaline lysis method (Bimboim \& Doly, 1979). $\lambda$ DNA was obtained as described by Grossberger (1987). After RNAase treatment, DNA was purified by phenol/chloroform extraction and precipitated by ethanol. The boiling method miniprep (Del Sal et al., 1988) was used to prepare DNA for cloning, deletion reactions and transformations. DNA fragments separated by elecrophoresis on $0.8 \%$ agarose gel were extracted from gel slices and purified by centrifugation through siliconized sterile glass wool (Heery et al., 1990).

DNA sequencing and analysis. Unidirectional deletions of the DNA fragments cloned in pMTL20EC were generated by a double-stranded nested deletion kit (Pharmacia). DNA sequencing on both strands was performed using the dideoxy chain-termination method (Sanger et al., 1977). Labelling reactions were performed with a Sequenase Version $2.0 \mathrm{kit}$ (USB) and $\left[\alpha^{-35} \mathrm{~S}\right] \mathrm{dATP}$ (Amersham). To sequence regions for which no suitable clones were available, site-specific primers (17-mers) were synthesized with an SM oligonucleotide synthesizer (Beckman). The sequence was compiled and analysed by the University of Wisconsin Computer Group software (Devereux et al., 1984).

Transformation. Competent cells of $E$. coli DH5 were prepared and transformed by the procedure of Chung \& Miller (1989). Transformation of $B$. subtilis was performed as described by Karamata \& Gross (1970). Erythromycin-resistant transformants of $B$. subtilis were selected on LB medium containing $0.25 \mu \mathrm{g}$ erythromycin $\mathrm{ml}^{-1}$. They were transferred to the same medium containing a 100 -fold higher concentration of the antibioiic.

Hybridization. For Southern hybridization (Southern, 1975) endonuclease fragments of chromosomal DNA were transferred from agarose gel to Hybond- $\mathrm{N}$ nylon membranes (Amersham) by alkali blotting (Reed \& Mann, 1985).

Amidase and modifier detection. Cells grown to a concentration of $10^{8}$ cells $\mathrm{ml}^{-1}$ in SA medium were washed with cold double-distilled water. Cell wall proteins were extracted with $5 \mathrm{M}-\mathrm{NaCl}, 50 \mathrm{~mm}$-Tris pH 8.0 (Margot \& Karamata, 1992), and analysed by SDS-polyacrylamide $(12 \%, w / v)$ electrophoresis (Laemmli, 1970).

Autolysis. Cells were grown with aeration in SA medium at $37^{\circ} \mathrm{C}$ to a concentration of $10^{8}$ cells $\mathrm{ml}^{-1}$. After arrest of aeration, sodium azide was added at a final concentration of $0.05 \mathrm{M}$, and the decrease of nephelometric density was followed (Margot \& Karamata, 1992).

Determination of turnover kinetics. The procedure described by Pooley (1976) was followed.

Isolation of total RNA. Total cellular RNA was isolated from a culture grown in SA medium at $37^{\circ} \mathrm{C}$ and harvested at $10^{8}$ cells $\mathrm{ml}^{-1}$. The isolation procedure was essentially that of Gilman \& Chamberlin (1983). A $15 \mathrm{ml}$ volume of culture was transferred to a $50 \mathrm{ml}$ centrifugation tube containing ice chilled to $-20^{\circ} \mathrm{C}$. Cells were sedimented at $0^{\circ} \mathrm{C}(5 \mathrm{~min}$ at 10000 r.p.m., Sorvall rotor SS-34), resuspended in $0.5 \mathrm{ml}$ disruption buffer $(30 \mathrm{mM}-\mathrm{Tris} / \mathrm{HCl} \mathrm{pH} 7.5$, $100 \mathrm{~mm}-\mathrm{NaCl}, 5 \mathrm{~mm}-\mathrm{EDTA}, 1 \%$, w/v, SDS, $100 \mu \mathrm{g}$ proteinase $\mathrm{K} \mathrm{ml}^{-1}$ ), transferred onto ice, and disrupted by four $5 \mathrm{~s}$ sonications at $30 \mathrm{~W}$ with the microtip of an MSE sonifier, separated by $10 \mathrm{~s}$ intervals. Three extractions with phenol/chloroform/isoamyl alcohol $(25: 24: 1$, by vol.) at $55^{\circ} \mathrm{C}$ were followed by an extraction with chloroform/ isoamyl alcohol $(24: 1, v / v)$ and precipitation with ethanol. Precipitated nucleic acids were redissolved in $20 \mathrm{~mm}$-Tris/ $\mathrm{HCl}$ pH $8.0,10 \mathrm{~mm}$ $\mathrm{MgCl}_{2}, 2 \mathrm{mM}-\mathrm{CaCl}_{2}$ and $100 \mu \mathrm{g} \mathrm{ml}^{-1}$ of proteinase-K-treated DNAase I (Tullis \& Rubin, 1980). After incubation for $60 \mathrm{~min}$ at $37^{\circ} \mathrm{C}$, SDS, EDTA and $\mathrm{NaCl}$ were added at final concentrations of $1 \%, 50 \mathrm{~mm}$ and $200 \mathrm{mM}$, respectively. The remaining RNA was extracted twice with phenol/chloroform/isoamyl alcohol $(25: 24: 1)$, once with chloroform/ isoamyl alcohol $(24: 1)$ and precipitated with ethanol.

Primer extension. Oligodeoxynucleotides 5'GCCGCCAGTTCCGAGTACAAGAAG3' and 5'ACTATTAACCCCGCAACCCGAAAG3' were prepared with the Beckman SM oligonucleotide synthesizer for the analysis of lytR and lytABC transcripts, respectively. They were purified on a $19 \%$ polyacrylamide gel. Twenty

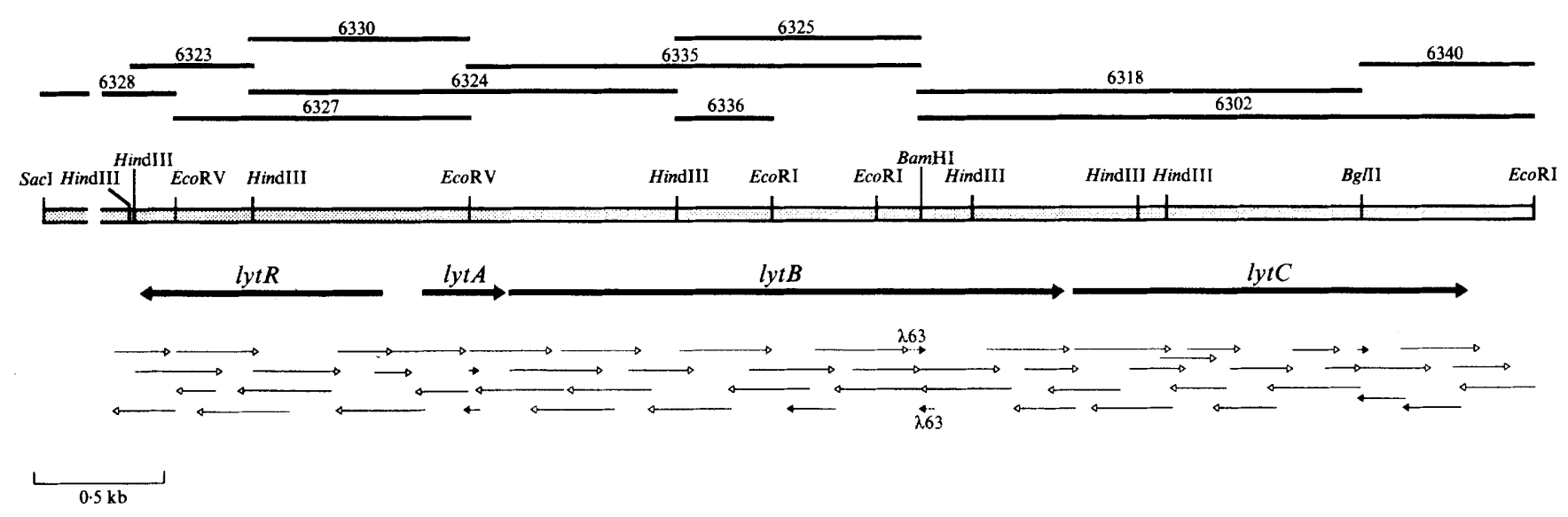

Fig. 1. Sequencing strategy. The $5280 \mathrm{bp}$ sequence as a part of the $6.1 \mathrm{~kb}$ SacI-EcoRI region was determined on both DNA strands using sets of nested deleted inserts derived from plasmid subclones (- Thin arrows correspond to the extent of DNA sequences determined from the single labelling reaction using the M13 $(\longrightarrow)$ or synthesized primers $(\longrightarrow)$. Position of ORFs is given under the restriction map $(\longrightarrow)$. Sequences determined by using the $\lambda 63$ DNA as template are indicated by dotted arrows $(\cdots \cdots . . \triangleright)$ labelled $\lambda 63$. 
HindII HindII

GITTCATTACGGGTATCGNAMAGACAACCGGATTCATTTACAGGCAAATAMAMAGAAGCTITGCACATTGTGCGAAGEITCTTTTTGTT

CAAAGTAATGCCCATAGCTTTTCTTGTTGGCCTAAGTAAATGTCCGTTTATTTTTTCTTCGAAACGTGTAACACGCTTCGMAGAAAACAAAATGAAAAGCTCCGAAAGGMAGTCGAGA 120

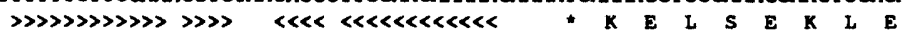

AACATTATAGCCTTTCCCGCGAAGTAGTCGAACCATCATCATTTMGGTAACTAAAAGCACGGACATGGAMATCAAGCACGACAAATTATACAMAgGCGCGTGGAAACATTAGCCTGA 240

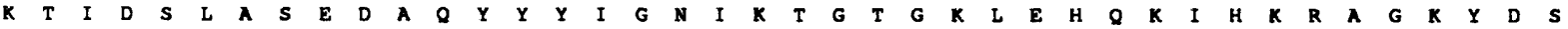
EcoRV

CGTATAGGGTGTACMATAGCTTCCAGTTCAAGCAAMAGTGTAATAAAAGTTGTTGMATTTGTATAGAGGCTTAAAGCACTACCTTCTTTATAMTCGCGGMATAATTATTATGGAACCT 360

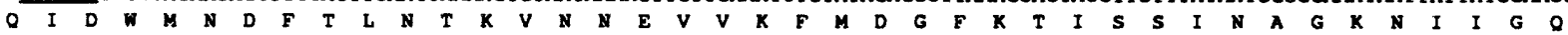

ACTGMACCGCGACCGCCAGGACCGCAGGCTTCAGCGGAGAGCCTAGAAGAAAAGATAGGCCCATATTCGCTCGCGMAGANAAGGCAAGTCGCACTAMAGAGGAMACGGCTTGCTTATTG 480

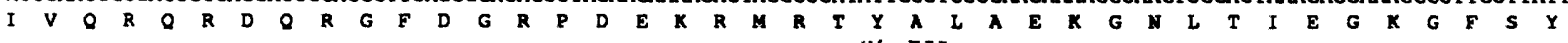
GCATdIII

GCAGTATTGACTTGCGCTTACACGACAATTGACATTACGGCGGTTCACATAGTTGTTGCAGAGATTLCGAMAGTACAAGTGAAGTGTTTTATTAGTTGGCCTTGTAGCTCCTTCAAGA GTTGTCACAGATGGCAGTAGACACACGGCGGCTTTCGCATACTTACCAACTAAMATAGGTMCACGGNAMGGCTATTAANACATATGCACAGTGCGCCTTACGACTGGTACAGCCAAC 720 $\begin{array}{llllllllllllllllllllllllllllllllllllllll}E & V & T & D & V & T & M & O & T & G & G & F & A & Y & S & H & N & I & K & D & M & T & G & K & G & I & I & K & T & Y & T & D & R & P & I & S & V & M & D & T\end{array}$

ATAAGCAAAAACCCAATTGCCAGTATATTTACTCGCATAGCCGTGCCGGGAATAGCGGCAGCGCMGTAGGTGTGGGTACTAATTCTGCCTTTTTCCTAGMAAAAATMACTATGACTGGA 840

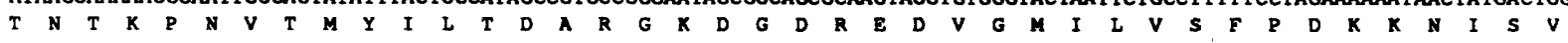

GAAATAGGGAGANAATCTAAATAGTTACGAAAGTACTTATGAACGGTGCCAACTTCGACGAMTACGGTATTCATCATACGTATCGGCGGTCAAGGCTCATGTTCTTCAGGCTAATAGC 960

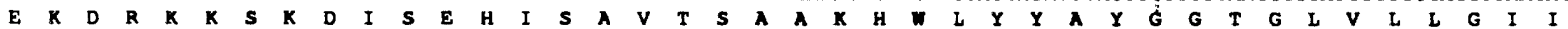

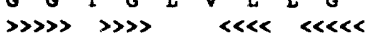

CCTTTGCACCTCGTCTGTTANATTACTTTCATTATGAGTTAAATTTCCAATAAATACAACTCTATTTA 1080

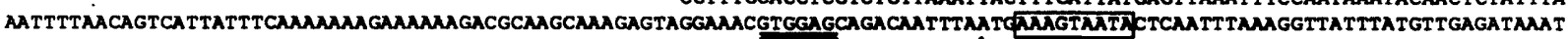
T L L I

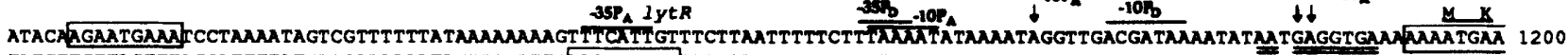

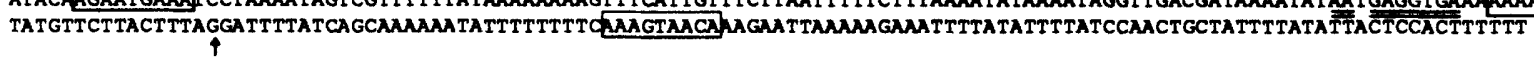

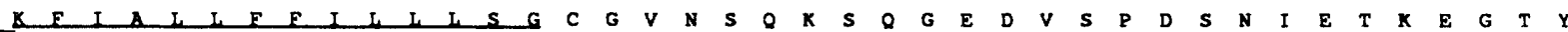

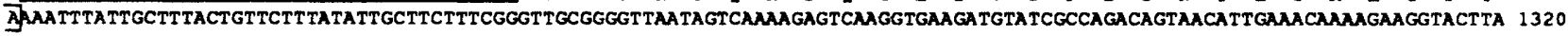

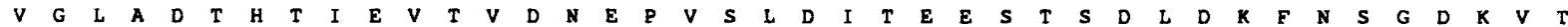

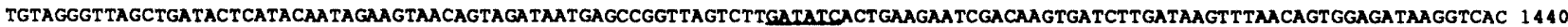
I T Y E K N D E G O I L L K D I E R A N E

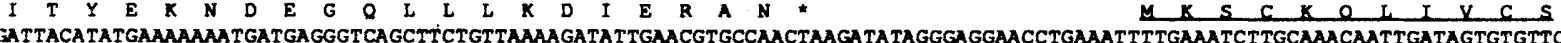

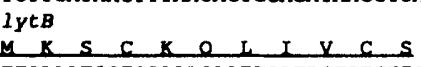

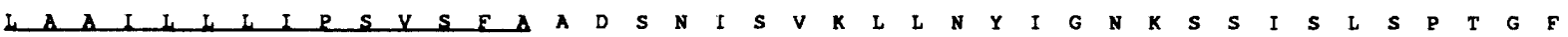
CTTGCTGCAATCTTATTATTGATTCCATCAGTTTCTTTTGCAGCAGACTCAAACATCTCAGTTAMATTGTTANATTATATTGGAMATANATCTAGCATCAGTCTATCGCCAACAGGATtT 1680

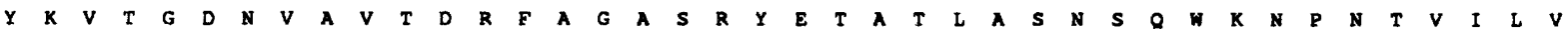

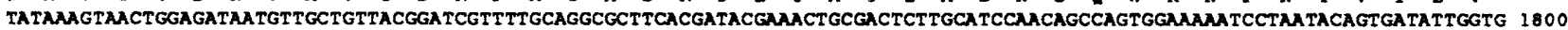

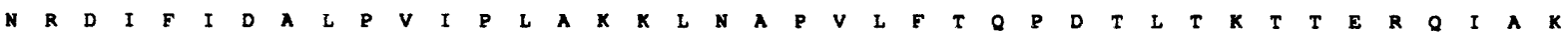

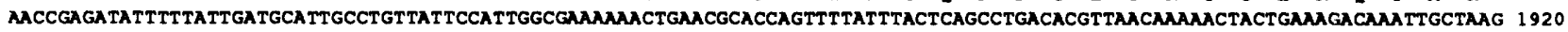

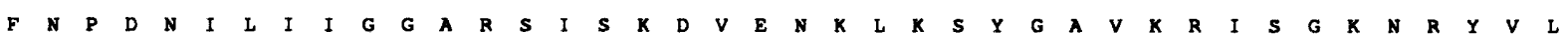

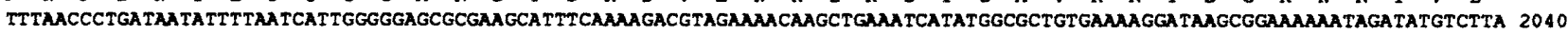

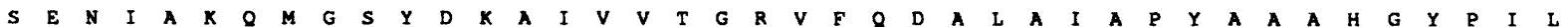

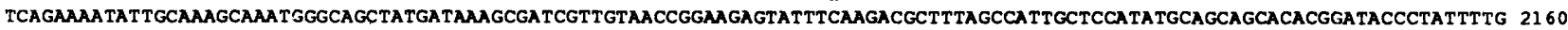

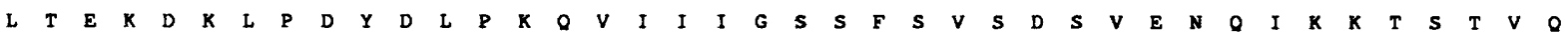

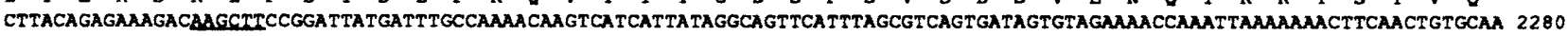
HIndII I

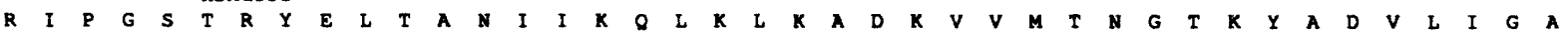
AGgATTCCTGGATCAACCAGATATGAACTTACGGCAMATATAMTMAGCAACTAMAGTTGAGGCTGATAMAGTCGTAATGACGMACGGGACAAAATATGCAGACGTATTGATAGGCGCT 2400

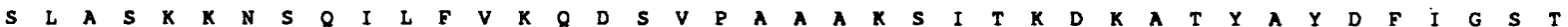

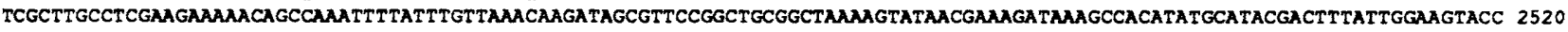

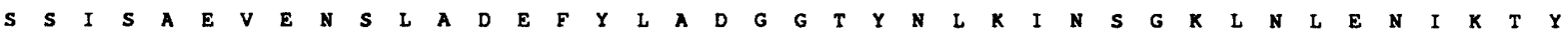

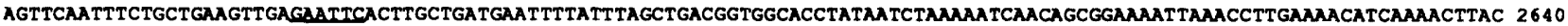
ECORI

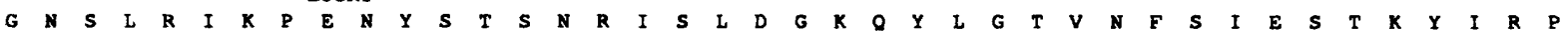
GGAAATCCCTAAGA TTAAACCAGAAAACTATTCTACTTCAAACA GAATTAGTCTTGATGGAAGCAGTATCTTGGCACGgTTAATTTCTCTATTGAGTCTACTAAATATATCCGACCG 2760

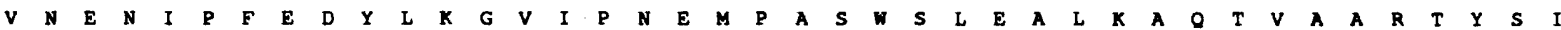
GTAAATGAGATATTCCATTTGAGGATTACTTAAAAGGATAATTCCGATGAAATGCCTGCTAGCTGGTCACTTGAgGCTCTTAAAGCACAGACTGTCGCTGCAAGAACCTACTCAATA 28вO

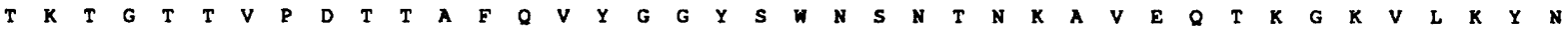

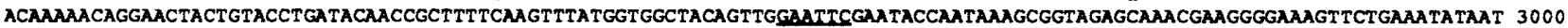
ECORI

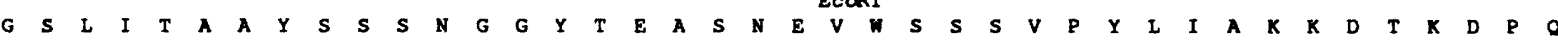

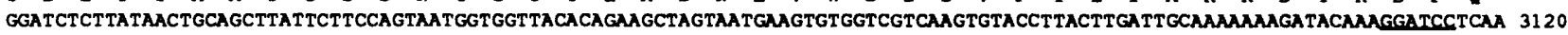
I Gami ATAGGCTGGACGCTTACTTTGTCAAAACAACAGCTAGATACGAAATCTTTGGACTIAACGAGCCTICTTCTTGGTGGTCTTCAGCGACTGAAACTGATTCTGCMAGACTTTCCGGAGTT 3240

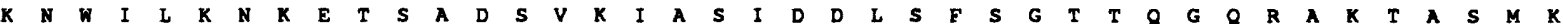
AAGACTGGATCTTGAAAATAAAGAACAAGCGCTGATTCTGTCANAATTGCAAGTATTGACGATTTAAGCTTAGTGGACGACACMAGGCAGCGTGCAANACAGCATCGATGAAA 3360 HindII I 


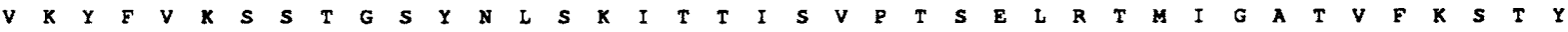
GTGAAGTATTTTGTTAAAAGCAGTACTGGCTCCTATAACTTGAgCAAAATTACAACCATTAGTGTACCAACAAGTGAGTTAAGACAATGATTGGAGCGACTGTATTTAAAATACTTAT 3480

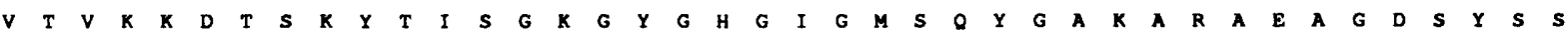
GTGACTGTAAAAAAAGATACTTCAMAGTACACA TCAGCGGTAAAGgATATGGTCACGGGATCGgAATGAGTCAATATGGAGCAAAAGCAAGAGCAGAAGCTGGAGATTCATATAGTTCA 3600

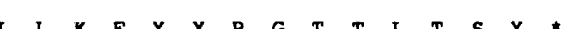

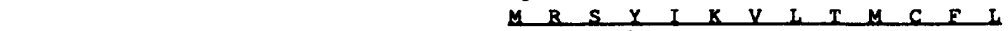
ATTTTGAAATTTTACTATCCAGGTACAACTCTGACAAGTTATTGATTATTTTAGGATATAACGCCATTTAAGgaggaAATCAATTGCGTTCTTATATAAAAGTCCTAACAATGTGTTTC 3720

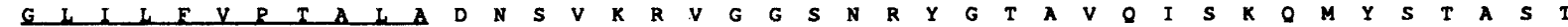

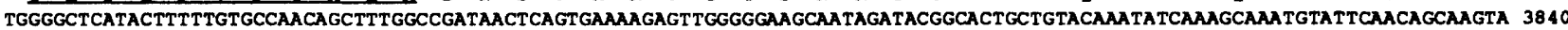

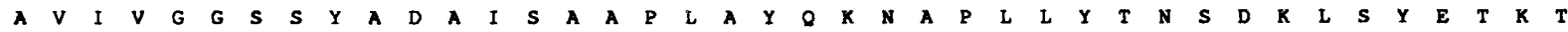
CAGCTGTAATTGTTGGTGGGATTCCTATGCAGATGCTATTTCAGCAGCACCTCTTGCTTACCAGAGAATGCGCATTGCTTTACACTAATCTGATAAGCTTTCATATGAAAGAAAA 3960 HindII I

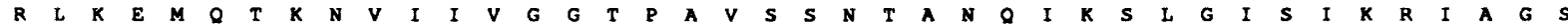

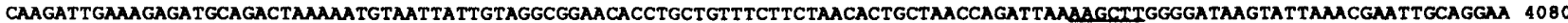
HIndIII

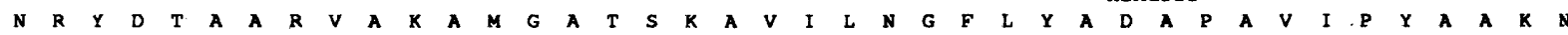
GCAACCGTTATGATACGGCTGCACGGGTGGCAAAAGCGATGGGTGCGACTTCAAAAGCTGTTATTTTGAACGGCTTCTTATATGCAGACGCTCCGGCCGTCATCCCTTATGCAGCGAAAA 4200

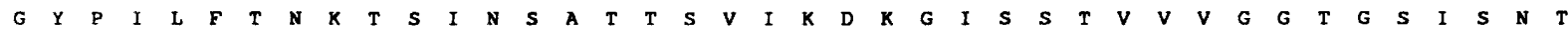

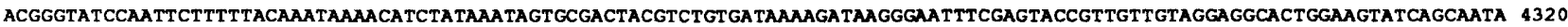

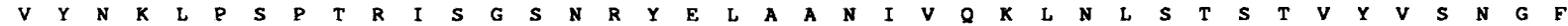
CGGTATACAACAAGTTACCTTCTCCTACAAGAATTAGCGGTTCANACAGATATGAGCTTGCTGCANATATCGTACANAACTTAATTTATCAACAAGCACCGTATATGTAAGCAATGGAT 440

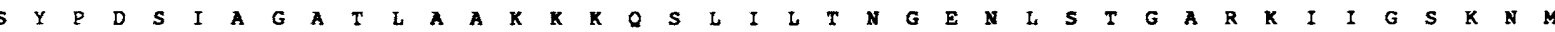
TCAGCTACCCTGACTCTATTGCAGGAGCTACACTGGCAGCTAAGAAGAGCAATCTCTTATTCTTACANATGGTGAMATTTATCTACAGGAGCCCGTAANATTATTGGAGTAAAAACA 4560

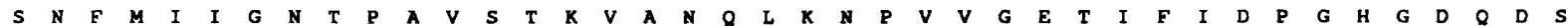
TGTCAAACTTTATGATTATCGGAAACACTCCTGCCGTAAGCACAAAGGTTGCTAATCAGCTAAAGANCCAGTTGTAGgTGANACAATCTTTATTGATCCGGGTCACGGTGATCAAGATT 4680

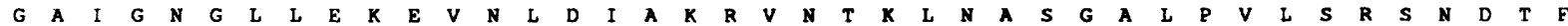
CAGGAGCAATCGGCAATGGACTCCTTGAGAAAGAGTCAACCTTGATATAGCGAAMGAGTCMATACAMGCTAMATGCTTCAGGTGCTCTTCCAGTACTGTCAAGATCTAATGATACTT 4800

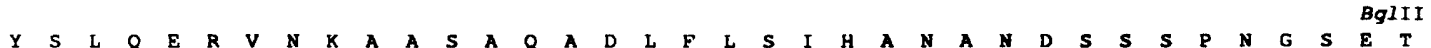

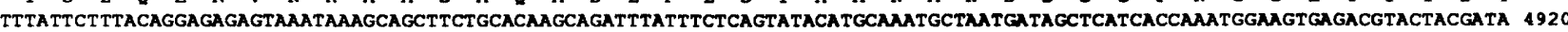

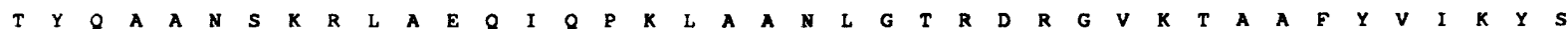
CAACATATCAAGCTGCAAATAGCAAGAGACTGGCTGACANATTCAACCANATTAGCGGCTAATCTTGGACGAGAGACCGgGGGTANAACAGCTGCTTTCTATGTTATTAAATATT 504O

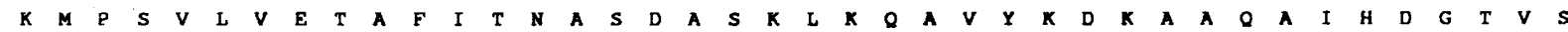
CTAAAATGCCGAGTGTTTTAGTTGAAACTGCCTTTATCACTAATGCATCAGATGCAAGTAAATTGAAGCAAGCGGTTTATAAAGATAAAGCTGCACAMGCTATTCATGACGGCACAGTAT 51 60

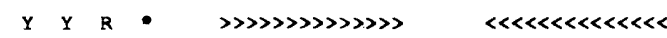

CTTATTACAGATAATCGAAAGAGACAAATCTAATCACAGATTTGTCTCTTTTTTATATGAAATGATTAAAACAAATAGGACTTGTATATAAAATAGTAAAAGAGTATTAACAACATTTAT 5280 AGCTTTCTCTGTTTAGATTAGTGTCTAAACAGAGAAAAAATATACTTTACTAATTTTGTTTATCCTGAACATATATTTTATCATTTTCTCATAATTGTTGTAAATA
\end{abstract}

Fig. 2. Nucleotide sequence of the 5280-base region. Both strands of DNA are shown only in the intergenic region between $l y t A$ and $l y t R$, and downstream from $l y t C$ and $l y t R$. Asterisks denote stop codons. Endonuclease cleavage sites are underlined. Deduced amino acid sequences are given in single-letter code. The $\mathrm{N}$-terminal amino acid signal peptide sequences (von Heijne, 1986; Yamaguchi et al., 1988) of LytA, LytB and LytC proteins are underlined. Ribosome-binding sites (only bases complementary to 16S rRNA) are doubly underlined. -35 and -10 promoter regions are marked. Converging arrowheads indicate dyad symmetry. Vertical arrows indicate start points of transcription. Nonamer repeats ANAATGAAA are boxed.

Table 2. Properties of the nucleotide sequence of the lyt $A$, $B, C$ and $R$ genes

\begin{tabular}{|c|c|c|c|c|c|c|c|}
\hline Property & $l y t R$ & $183^{*}$ & $l y t A$ & $23^{*}$ & lyt $B$ & $38^{*}$ & lytC \\
\hline Size of the ORF (bp) & 918 & & 306 & & 2115 & & 1488 \\
\hline Start codon & AUG & & AUG & & UUG & & UUG \\
\hline Stop codon & UAA & & UAA & & UGA & & UAA \\
\hline TA in wobble & & & & & & & \\
\hline $\begin{array}{l}\text { position } \\
\text { CAI } \dagger\end{array}$ & $\begin{array}{l}0.44 \\
0.49\end{array}$ & & $\begin{array}{l}0.14 \\
0.44\end{array}$ & & $\begin{array}{l}0.70 \\
0.46\end{array}$ & & $\begin{array}{l}0.12 \\
0.44\end{array}$ \\
\hline$\Delta G$ for $\mathrm{RBS}$ & & & & & & & \\
\hline$\left(\mathrm{kcal} \mathrm{mol}^{-1}\right) \ddagger$ & -13.8 & & $-16 \cdot 0$ & & $-14 \cdot 4$ & & $-19 \cdot 8$ \\
\hline TA $(\%)$ & 0.58 & & 0.64 & & 0.62 & & 0.61 \\
\hline
\end{tabular}

* Numbers of bp separating the adjacent ORFs. The numbers do not comprise the stop codons.

$\uparrow$ Codon Adaptation Index (Sharp \& Li, 1987).

$\ddagger$ Calculated according to the rules of Tinoco et al. (1973) ( $1 \mathrm{kcal}=4 \cdot 184 \mathrm{~kJ})$. picomoles was radiolabelled in a $50 \mu \mathrm{l}$ mixture with 20 units of T4 polynucleotide kinase (Biofinex) and $100 \mu \mathrm{Ci}(3.7 \mathrm{MBq})$ of $\left[\gamma^{-32} \mathrm{P}\right] \mathrm{ATP}$ ( $>5000 \mathrm{Ci} \mathrm{mmol}^{-1}$, Amersham), and purified by ethanol precipitation (Sambrook et al., 1989). Primer extensions were performed with $1.5 \mathrm{pmol}$ of these probes and 30 to $50 \mu \mathrm{g}$ of total cellular RNA according to Jones et al. (1985). Primers were annealed to RNA for $60 \mathrm{~min}$ at $55^{\circ} \mathrm{C}$ in $10 \mu \mathrm{l}$ of $10 \mathrm{~mm}$-Tris/ $\mathrm{HCl} \mathrm{pH} 8.0,1 \mathrm{~mm}$-EDTA, $1.25 \mathrm{M}-\mathrm{KCl}$, cooled to room temperature, centrifuged briefly, and diluted with $47 \mu \mathrm{l}$ of reverse transcription buffer $[20 \mathrm{mM}-\mathrm{Tris} / \mathrm{HCl}$, $10 \mathrm{~mm}-\mathrm{MgCl}_{2}, 5 \mathrm{~mm}$-dithiothreitol, $0.35 \mathrm{~mm}$-dNTPs, $100 \mu \mathrm{g}$ actinomycin $\mathrm{D} \mathrm{ml}^{-1}, 0 \cdot 1$ unit RNAase inhibitor (Biofinex) $\mu^{-1}$ ] to which 12 units of AMV reverse transcriptase (Biofinex) was added. Primer extensions were incubated for $60 \mathrm{~min}$ at $37^{\circ} \mathrm{C}$, extracted once with phenol/chloroform/isoamyl alcohol $(25: 24: 1)$ and ethanol precipitated. Pellets were resuspended in $5 \mu 150 \%(\mathrm{v} / \mathrm{v})$ formamide and loaded onto polyacrylamide sequencing gels. After autoradiography, bands were cut off the gel and their radioactivity measured in a liquid scintillation spectrometer using the ${ }^{3} \mathrm{H}$ window (Cerenkov radiation). 


\section{Results}

\section{Nucleotide sequence of the lytRABC divergon}

The DNA segment encompassing the structural genes of the amidase and of its modifier (Margot \& Karamata, 1992) was sequenced on both strands between restriction sites $S a c I$ and EcoRI according to the strategy described in Fig. 1. Computer analysis of the nucleotide sequence (Fig. 2), the main features of which are summarized in Table 2, revealed a functional unit consisting of two divergently transcribed operons: the operon lyt $A B C$ transcribed in the direction of DNA replication, consisting of three ORFs, and the monocistronic operon lyt $R$, transcribed in the opposite direction. The divergon, comprising $5160 \mathrm{bp}$, is flanked on each side by a rhoindependent terminator. The segment encoding the terminator of lyt $R\left(\Delta G=-16.2 \mathrm{kcal} \mathrm{mol}^{-1}\right.$; Freier et al., 1986) fulfils the same function for adjacent, convergently transcribed, orf $X$ (B. Soldo, unpublished). The terminator of lytC $\left(\Delta G=-16.1 \mathrm{kcal} \mathrm{mol}^{-1}\right)$ is flanked by a non-coding region extending over at least $450 \mathrm{bp}$ (V. Lazarevic, unpublished). Comparison of the sequenced subclones with those used for insertional inactivation of the modifier and the amidase (Margot \& Karamata, 1992) revealed that the latter proteins are encoded by the $l y t B$ and $l y t C$ genes, respectively. The two operons are separated by a regulatory region of $183 \mathrm{bp}$. lyt $A$ is separated from $l y t B$ by $23 \mathrm{bp}$, and lyt $B$ from lyt $C$ by $38 \mathrm{bp}$ (Table 2). It is noteworthy that both intercistronic spacers are within the limit of $66 \mathrm{bp}$ which is compatible with translational coupling (Petersen, 1989). Indeed, translation of both $l y t B$ and $l y t C$ starts with the relatively unusual UUG initiation codon, which does not allow de novo translational initiation (Adhin \& van Duin, 1989). $\Delta G$ s for RBSs range from $-13.8 \mathrm{kcal}$ $\mathrm{mol}^{-1}$ for $l y t R$ to -19.8 for $l y t C$. They may reflect differences at the level of the efficiency of gene expression (Sharp et al., 1990). The estimation based on the percentage of $A / T$ base pairs in the wobble position suggests that ORFs belonging to the lyt $R$ and $l y t A B C$ operons are expressed at very different levels; the expression of the former ORF would be rather moderate while that of the latter ORFs would be extremely high (Shields \& Sharp, 1987). However, values (Table 2) of the codon adaptation index (CAI), considered to provide a more realistic measure of the gene expression level, suggest that all four genes are moderately expressed.

\section{Analysis of deduced products encoded by lyt $A, B, C$ and $R$ ORFS}

The predicted products of ORFs $l y t A, l y t B$ and $l y t C$ consist of 102,705 and 496 amino acid residues, corresponding to proteins with molecular masses of $11 \cdot 2$,
Table 3. Features of amino acid products deduced from the nucleotide sequences of the lyt $R, A, B$ and $C$ genes

\begin{tabular}{lcccc}
\hline \multicolumn{1}{c}{ Property } & LytR & LytA & LytB & LytC \\
\hline Uncleaved & & & & \\
$\quad$ No. of amino acids & 306 & 102 & 705 & 496 \\
$\quad$ Mol. mass (kDa) & 34.6 & $11 \cdot 2$ & 76.7 & 52.6 \\
Mature* & & & & \\
$\quad$ No. of amino acids & 306 & 86 & 680 & 472 \\
Mol. mass (kDa) & 34.6 & $9 \cdot 4$ & $74 \cdot 1$ & 49.9 \\
Isoelectric point & $10 \cdot 0$ & 3.9 & $10 \cdot 3$ & 10.6 \\
Net charge & 7 & -13 & 26 & 23 \\
\hline \hline
\end{tabular}

* LytA, LytB and LytC proteins possess a signal peptide (Fig. 2)

76.7 and $52.6 \mathrm{kDa}$ (Table 3). All three proteins are apparently endowed with signal peptides (Fig. 2) allowing passage through the cytoplasmic membrane. LytB and LytC were expected to possess signal peptide since they are CWBPs. The calculated molecular masses of their cleaved products $-74 \cdot 1$ and $49.9 \mathrm{kDa}$, respectively - correspond to those of the modifier and the amidase obtained by SDS-PAGE analysis (Margot \& Karamata, 1992). Both polypeptides are highly basic, with isoelectric points of 10.3 and $10 \cdot 6$, respectively; this is in good agreement with their high affinity for cell wall containing teichoic acid (Herbold \& Glaser, 1975; Studer, 1988). The deduced product of lytA, a 102 amino acid polypeptide, is highly acidic (Table 3 ). Its N-terminal peptide, a signal peptide specific to lipoprotein, is followed by a hydrophilic amino acid sequence. The deduced product of $l y t R$, a basic protein, could be membrane-anchored by its $\mathrm{N}$-terminal part - from residue 11 to 35 - which is homologous to transmembrane domains of many eukaryotic glycoproteins (Birchmeier et al., 1986; Krupinski et al., 1989). The LytB and LytC proteins show significant homology (Fig. 3). They each contain three homologous domains of about 100 amino acids in their $\mathrm{N}$-terminal moieties (Fig. 4). Sequence analysis also revealed a homology between the C-terminal moiety of LytB and the spoIID gene (Lopez-Diaz et al., 1986) product (Fig. 3).

\section{Transcription of the lyt $A B C$ and lyt $R$ operons in vivo}

Search for putative transcription signals has revealed that all potential promoters are grouped in the $183 \mathrm{bp}$ regulatory region which separates $l y t R$ from $l y t A$ (Fig. 2). In addition, this region contains four $9 \mathrm{bp}$ sequences organized as two inverse repeats, which may play a regulatory role (Bohannon \& Sonenshein, 1989), as well as an operator-like structure overlapping with $\mathrm{P}_{\mathrm{A}, 2}$.

In vivo transcription starts were determined by the primer extension method. Two DNA oligonucleotides 
(a)

\begin{tabular}{|c|c|c|c|}
\hline Lytc & 1 & LRSY IKVLTMCF LGLI LFVP--- TALADNSVK- & 66 \\
\hline & & $1: 1: \quad:: \quad::::: 1:: 1$ & \\
\hline Lyt B & 1 & LKSCKQLIVCSLAAILLLIPSVSFAADSN ISVKLLNYIGNKSSISLSPTGFYKVTGDNVAVTDRFAGASRYETATLASNSQWKNPNTVILVNRDIF IDAL & \\
\hline Lytc & 67 & SAAPLAYQKNAP LLYTNSDKLSYETKTRLKEMQTKNVI IVGGTPAVSSNTANQIKSLGISIKRIAGSNRYDTAARVAKAMGATSKAVILNGFLYADAPAV & \\
\hline & & $1:: 1: 11:: 1:|:| 1||:|1||1| 1$ & \\
\hline Lyt B & 101 & PVIPLAKKLNAPVLFTQPDTLTKTTERQIAKFNPDNILIIGGARSISKDVENKLKSYG AVKRISGKNRYVLSENIAKQMGSYDKAIVVTGRVFODALAI & \\
\hline LytC & 167 & IPYAAKNGYPILFTNKTSINSATTSVIKDKGISSTVVVGGTGSISNTVYNKLPSPT---RISGSNRYELAANIVQKLNLSTSTVYVSNGFSYPDSIAGAT & \\
\hline & & $|1| 1|1| 1|1|:|1|$ & \\
\hline Lyt B & 200 & APYAAAHGYPILLTEKDKLPDYDLP-----KQVIIIGSSFSVSDSVENQIKKTSTVQRIPGSTRYELTANI IKQLKLKADKVVMTNGTKYADVLIGAS & \\
\hline $\mathrm{tc}$ & 264 & :LLEK-- - & \\
\hline & & $1:: 1$ & \\
\hline
\end{tabular}

(b)

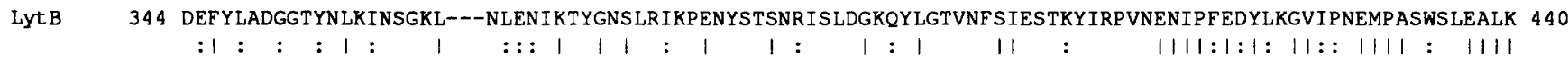
SPOIID 2 KQFAITLSVLCALILLVPTLLVIPFQHNKEAGAS--VESEKTAVSTKPASKGAETLKASPVSIPVYRTANQSVENIPLEEYVIGVVASEMPATFKPEALK 99

LYTB 441 AQTVAARTYSI---_-_-_- TKTGTTVPDTTAFQVYG--_-_-_GYSWNSNTNK---AVEQTKGKVLKYNGSLITAAYSSSNGGYTEASNEVWSSSV 518

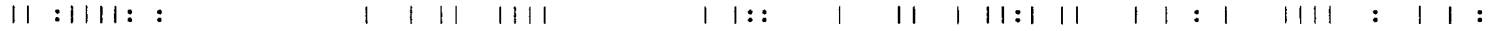

SPOIID 100 AQALAARTF IVRLMVSNSAVEAPKGSLVDDTQMFOVYKSKAELKKQWGTSYETKLKKITDAVASTQGKILTYNNQPIEASFFSTSNGYTENAEAYWTSAI 199

LYtB 519 PYLIAKK---DTKDPQIGWTLTLSKQQLDTKSLDLTKPSSWWSSATETDSARLSGVKNWILKNKETSADSVKIASIDDLSFSGTTQGQRAKTASMKVKYF 615

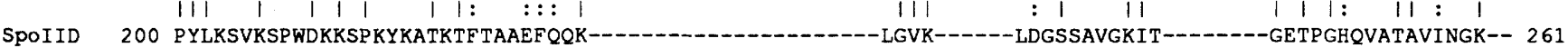

LYT B 616 VKSSTGSYNLSKITTISVPTSELRTMIGATVFKSTYVTVKKDTSKYTISGKGYGHGIGMSQYGAKARAEAGDSYSSILKFYYPGTTLTS 704

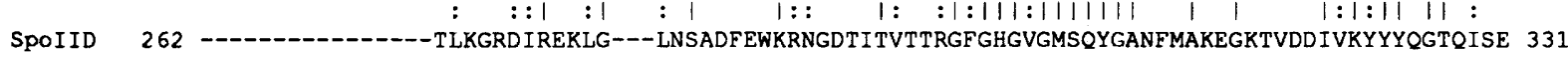

Fig. 3. Comparison of the amino acid sequences: (a) LytC and the $N$-terminal moiety of LytB, (b) C-terminal moiety of LytB and SpoIID. Identical ( 1 ) and conserved (:) residues are indicated. Amino acid numbers are specified for the extremities of each segment.

\begin{tabular}{|c|c|c|}
\hline \multirow[t]{2}{*}{ LytB } & 64 & LASNSQWK . NPNTVI LVNRD IF IDALPVIP LAKKLNAPVLF TQPD TLTKTTERQI AKFNPDN I LI I GGARS I SKDVENKLKSYGAVK \\
\hline & 162 & PKQVIIIGSSF SVSDSVENQIKKTSTVQ \\
\hline & 252 & 2LKLKADKVVMTNGTKYADVLIGASLASKKNSQILFVKODSVPAAAKS ITKDKATYAYDF IGSTSSISAEVENSLADEFYLA \\
\hline \multirow[t]{3}{*}{ Lytc } & 30 & RVGGSNRYGTAVQIS KQMYSTASTAVIVGGSSYADAISAAPLAYQKNAPLLYTNSDKLSYETKTRLKEMQTKNVIIVGGTPAVSSNTANQIKSLGISIK \\
\hline & 129 & RIAGSNRYDTAARVA KAM.GATSKAVILNGFLYADAPAVIPYAAKNGYP ILFTNKTS INSATTSVIKDKGISSTVVVGGTGS ISNTVYNKLPSPT \\
\hline & 223 & RISGSNRYELAANIV QKLNLSTSTVYVSNGF SYPDS I AGATLAAKKKOSL I LTNGENLSTGARKI IGSKNMSNFMI IGNTPAVSTKVANQLKNPVV \\
\hline
\end{tabular}

Consensus

Ri-GsnRYelaani- kqm----skvv-vnG--yaDala-aplAakkn-pilftn-d-1---t----ik-k---n--iiGgt-siS--veNqIks---.-$t$ ta

Fig. 4. Alignment of domains of LytB and LytC. The consensus line shows absolutely conserved residues (upper-case), consensus (at least three out of six residues conserved; lower-case); $(-)$ absence of consensus according to given criteria; (.) no residue.

belonging to the predicted $l y t A B C$ and $l y t R$ transcripts were ${ }^{32} \mathrm{P}$ end-labelled at their $5^{\prime}$-terminus. It is expected that, in the presence of a molar excess of oligonucleotide primers, the amount of label found in a band of the extended primer will be directly proportional to the amount of RNA added to the extension reaction (Sambrook et al., 1989). Indeed, for lytR and lyt $A B C$ transcripts, the strength of the signals was directly proportional to the amount of RNA added, over the range from 10 to $100 \mu \mathrm{g}$ of total wild-type RNA (not presented). Start sites could be localized by comparison with a sequencing ladder (Fig. 5). For lyt $A B C$ transcripts, one site was found 8 nucleotides downstream of the end of the characteristic $P_{D}$ promoter consensus (Fig.
2) (Gilman et al., 1981). This transcript was absent in strain L16006, in which the sigD gene was disrupted, confirming the $\sigma^{\mathrm{D}}$ dependence of this site. This promoter corresponds indeed to $\mathrm{P}_{28-7}$, belonging to the collection of $P_{D}$ promoters identified by Gilman et al. (1984) and sequenced by Singer (1987). That this transcript was increased about fourfold in strain L16020, in which the divergently transcribed $l y t R$ gene was disrupted, provides strong evidence of an interdependence between operons $l y t A B C$ and $l y t R$. Analysis of $l y t A B C$ transcripts (Fig. 5) revealed another start site, localized 21 nucleotides upstream of that initiated by $\sigma^{\mathrm{D}}$. The former corresponds to a putative $\mathrm{P}_{\mathrm{A}}$ promoter (Fig. 2), designated $P_{A, 1}$ (see below), which is localized 7 nucleotides 


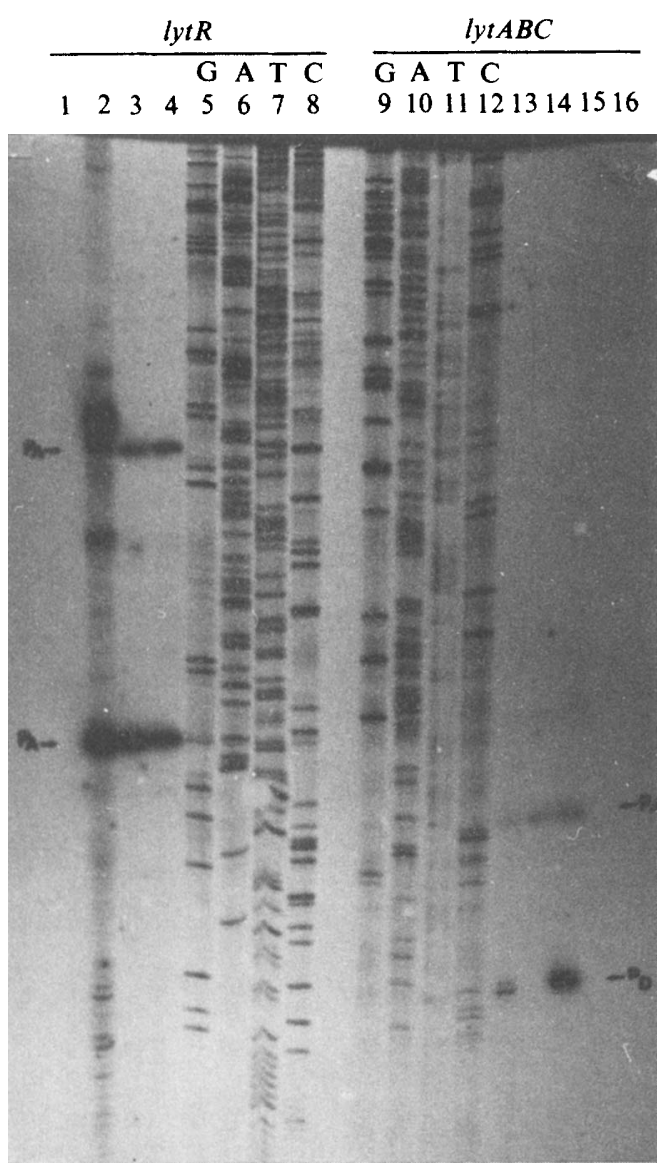

Fig. 5. Mapping by primer extension of the transcription start sites of the $l y t R$ and $l y t A B C$ operons. Lanes 5 to 8 , and 9 to 12 (GATC) show DNA sequencing ladders of the regions upstream of $l y t R$ and $l y t A B C$, respectively. Lanes 1 to 4 (probe $l y t R$ ) and 13 to 16 (probe $l y t A B C$ ) show the primer extension analysis. The same probes were used for sequencing. RNA samples were as follows: lanes 1 and 16 , no RNA; 2 and 15, RNA from strain L16020 lytR; 3 and 14, RNA from strain L16006 sig D; 4 and 13, RNA from the reference strain L5047.

upstream of the start site. This transcript was affected neither by the $s i g D$ nor by $l y t R$ mutations (Fig. 5). In the wild-type strain L5047, $29 \%$ of the transcripts are initiated by $\sigma^{\mathrm{A}}$, which is in excellent agreement with the amidase activity present in strains with a deficient sig $D$ gene (Marquez et al., 1990).

Analysis of the lyt $R$ transcript (Fig. 5) also revealed two start sites and, compared to lyt $A B C$, a high level of transcription. The first site lies 7 nucleotides downstream of the end of a putative $P_{A}$ promoter (Fig. 2), designated $\mathbf{P}_{\mathrm{A}, 2}$. Although presence of another promoter could not be inferred from the nucleotide sequence analysis, primer extension experiments have revealed an additional start site 61 nucleotides upstream of the first one. The neighbouring upstream segment bears no obvious resemblance to any of the inventoried promoter motifs. Although it could theoretically accommodate the -10 and -35 sequences of $a P_{A}$ promoter, it will be designated $\mathrm{P}_{\mathrm{X}}$ here below.

Transcription of $l y t R$ in mutant L16020 (lyt $R$ ) (see below) is initiated at no less than three sites, all different from that observed in the $l y t R^{+}$strain and considerably increased when compared to the latter. One of these sites, with an intensity comparable to that of the $P_{X}$ site in the $l y t R^{+}$strain, is localized $23 \mathrm{bp}$ downstream of the latter. The two remaining sites lie between 10 and $5 \mathrm{bp}$ upstream of the $\mathrm{P}_{\mathrm{X}}$-related site; the expression at the site closest to the latter is about seven times higher than that corresponding to $\mathrm{P}_{\mathrm{X}}$.

\section{Behaviour of lytA-and lytR-deficient mutants}

To inactivate the lyt $A$ gene, the chloramphenicol resistance (cat) gene located on the $1.1 \mathrm{~kb}$ EcoRI fragment of plasmid pWD1 was cloned into the unique Eco RV site of plasmid pV3, providing a new recombinant plasmid, designated $\mathrm{pLl}$. Transformation of strain L5047 with the $2.7 \mathrm{~kb}$ HindIII fragment of plasmid pL1 yielded chloramphenicol-resistant recombinants which were shown by Southern hybridization to possess a single cat gene inserted into lyt $A$. $\mathrm{NaCl}$ extracts of whole cells or native cell walls of strain L16013, a cat-bearing lytA recombinant, were subjected to SDS-PAGE analysis (not shown). It appeared that L16013 was devoid of $l y t B$ and $l y t C$ proteins, confirming that ORFs $l y t A, l y t B$ and lyt $C$ belong to the same transcription unit. Search for the LytA protein, whose molecular mass is $9.4 \mathrm{kDa}$ (mature protein), by inspection of $15 \%$ SDS-PAGE gels of either native cell wall or TCA-precipitated exoprotein (not shown) was unsuccessful. This supports the sequence analysis data suggesting the lipoprotein nature of LytA (see above).

To inactivate lytA while ensuring expression of $l y t C$, we constructed strain $\mathrm{L} 16015$ by insertion of plasmid p6325 $\Delta 1$ into the $l y t B$ gene of strain L16013, as revealed by Southern hybridization (not shown). In this strain, lyt $C$ was read by the constitutively expressed promoter of the erythromycin resistance gene of plasmid pMTL20EC (Brehm et al., 1987; Chambers et al., 1988). Indeed, $\mathrm{NaCl}$ extracts of strain $\mathrm{L} 16015$ revealed that CWBP49 was present. Cell autolysis, flagellar motility, as observed by the light microscope, and turnover kinetics of strains L16015 lyt $A^{-} B^{-} C^{+}$and L16016 lyt $A^{+} B^{-} C^{+}$did not differ significantly. Thus it appeared that LytA does not play an essential role for the amidase export and activity, at least in the absence of the modifier.

To inactivate the lyt $R$ gene, the $0.4 \mathrm{~kb}$ HindIII fragment from p6327 477 was cloned into plasmid pMTL20EC, and the resulting plasmid pA2 was inserted into the $l y t R$ gene. The chloramphenicol-resistant recom- 
binant L16020 thus obtained was shown by Southern hybridization to have a disrupted $l y t R$ gene. Although the LytR protein seems to play an effector role in the expression of the lytABC operon (see above), our preliminary experiments did not detect any physiological alteration of the $l y t R$ strain L16020. Indeed, its turnover kinetics and cell wall autolysis were identical to those of the parent strain L5047 (not shown).

\section{Discussion}

The $\mathrm{N}$-acetylmuramoyl-L-alanine amidase, one of the two major autolysins of $B$. subtilis 168 , was shown not to be essential for vegetative growth (Margot \& Karamata, 1992). It was suggested that the bulk of the activity of this CWBP, which has a high affinity for teichoic acid endowed peptidoglycan, is involved in flagellar morphogenesis (Pooley \& Karamata. 1984). However, physical and genetic studies have revealed that the in vivo activity and biosynthesis of this enzyme are subject to a rather complex regulation (see Introduction). The sequencing reported here of the regulatory unit which contains $l y t C$ (Fig. 2), the structural gene of the amidase, largely confirms this view. The main features of this unit, the lyt $R A B C$ divergon, are schematically represented in Fig. 6. The operon lyt $A B C$, transcribed in the direction of DNA replication, encodes an acidic, low-molecularmass protein (LytA), as well as the modifier (LytB) and the amidase (LytC). The monocistronic operon lyt $R$, transcribed in the opposite direction, encodes a $35 \mathrm{kDa}$ protein (LytR) whose only function so far identified is to attenuate expression of both operons of the lytRABC divergon.

The analysis of the deduced amino acid sequences encoded by this divergon provides an incomplete picture of the nature and role of proteins LytA, B, C and R. Mature LytA is a $9.4 \mathrm{kDa}$, highly acidic polypeptide. Its sequence strongly suggests that it is a lipoprotein (Yamaguchi et al., 1988), anchored to the cytoplasmic membrane via the $\mathrm{N}$-terminal glyceride-modified cysteinyl residue, and localized on its outer surface. By analogy to PrsA lipoprotein (Kontinen et al., 1991), it may play a role in the secretion of LytB and LytC. However, its inactivation affects neither cell growth nor export of the amidase. LytB, the so-called modifier, was shown in vitro to enhance the amidase activity by a factor of two to three. However, in vivo studies on strains with inactivated $l y t B$ or $l y t C$ genes leave open the question of its possible general amidase-enhancing activity or even of an intrinsic amidase activity (Margot \& Karamata, 1992). Sequence homology studies revealed a high homology between LytB and LytC in three repetitive domains localized within the $\mathrm{N}$-terminal moiety. These domains contain the consensus GSNRY motif found in nearly all amidases so far sequenced originating from different bacteria and phages (Table 4). The question of the role of this motif, i.e. recognition or catalytic activity remains open. Interestingly, the $\mathrm{C}$-terminal moiety of the LytB protein exhibits a high homology with the spoIIDencoded protein (Lopez-Diaz et al., 1986), which supports the hypothesis that the latter is involved in cell wall metabolism during spore formation (Illing \& Errington, 1991). LytC protein is responsible for the bulk of the amidase activity during vegetative growth. Strains with inactivated $l y t C$ are impeded neither in growth nor in cell separation. They have less than $3 \%$ of the amidase activity present in the parent strain and exhibit considerably reduced autolysis of either whole cells or native cell walls, as well as anomalies in cell wall turnover kinetics (Margot \& Karamata, 1992). Finally, LytR was shown to play an attenuator role for both its own and lyt $A B C$ operon expression as evidenced by considerably increased transcription frequency in a LytR-deficient strain (Fig. 5). It is noteworthy that an attenuator is endowed with a membrane-anchoring-like sequence. This basic protein is expressed at a rate five times higher than that of the amidase, suggesting an abundant protein which may play a role of a more general attenuator, affecting for example the expression of the other operons belonging to the flagellar regulon (see below). In addition, the motif identified in its deduced amino acid sequence is not a typical HTH one. It does not have a counterpart in inventoried DNAbinding proteins; the $T$ region is too short to allow a full turn, and the whole motif is smaller than the $60 \mathrm{bp}$ lower limit (Harrison \& Aggarwal, 1990).

At the transcriptional level, the operon lyt $A B C$ is under the control of a proximal $\mathbf{P}_{\mathrm{D}}$ and a more distal $\mathbf{P}_{\mathrm{A}, 1}$ promoter (Fig. 6) which, towards the end of the exponential growth phase, account for 70 and $30 \%$ of the amidase activity, respectively. The latter activity is in perfect agreement with amidase assays in sig $D$ - and $f l a B$ deficient strains (P. Margot, unpublished). Our observations reveal that absence of $L y t R$ is accompanied by a 4.4-fold enhancement of the lyt $A B C$ operon transcription from $\mathbf{P}_{\mathrm{D}}$. At the protein synthesis level it would appear that translation of $l y t B$ and $l y t C$ is subordinated to that of $l y t A$. Indeed, the $l y t B$ and $l y t C$ parts of the polycistronic mRNA have UUG as start codon, which was reported to ensure coupled translation through translational reinitiation (Adhin \& van Duin, 1989), i.e. only ribosomes fixed on a RBS of an upstream gene can translate a UUGstarting ORF. This system would account for equimolarity of LytB and LytC and suggests an absolute requirement of LytA for functioning of the operon. Nevertheless, strains with the lyt $A^{-} B^{-} C^{+}$genotype not only grow normally but are endowed with LytC at a 


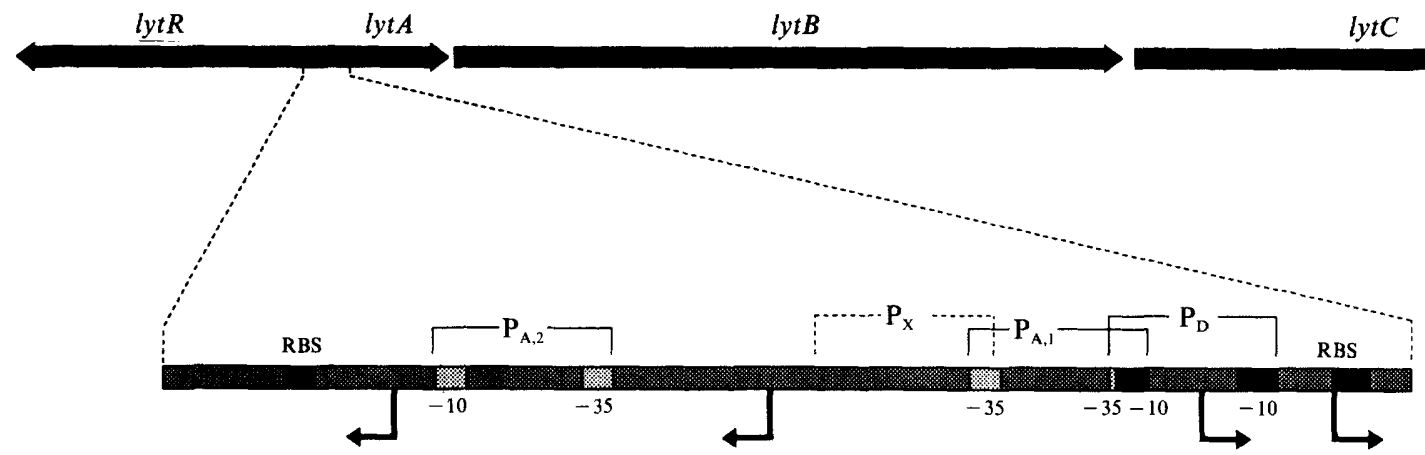

Fig. 6. Schematic drawing of the lytRABC divergon with an enlargement of the regulatory region.

Table 4. The five-amino-acid motif common to proteins endowed with an $\mathrm{N}$-acetylmuramoyl-L-alanine amidase activity and the modifier of the B. subtilis amidase

\begin{tabular}{|c|c|c|c|c|c|c|c|}
\hline Protein, organism & $\begin{array}{l}\text { Total } \\
\text { amino } \\
\text { acids }\end{array}$ & $\begin{array}{c}\text { Position of } \\
\text { relevant } \\
\text { motif }\end{array}$ & \multicolumn{4}{|c|}{ Motif } & Reference \\
\hline LytB, Bacillus subtilis & 705 & $\begin{array}{r}67 \\
165 \\
255\end{array}$ & $\begin{array}{l}\mathrm{G} \\
\mathrm{G} \\
\mathrm{G}\end{array}$ & $\begin{array}{ll}\text { A } & S \\
K & \mathbf{N} \\
S & T\end{array}$ & $\begin{array}{l}\mathbf{R} \\
\mathbf{R} \\
\mathbf{R}\end{array}$ & $\begin{array}{l}Y \\
Y \\
Y\end{array}$ & This work \\
\hline LytC, Bacillus subtilis & 496 & $\begin{array}{r}33 \\
132 \\
226 \\
406\end{array}$ & $\begin{array}{l}G \\
G \\
G \\
G\end{array}$ & $\begin{array}{ll}S & N \\
S & N \\
S & N \\
S & E\end{array}$ & $\begin{array}{l}\mathbf{R} \\
\mathbf{R} \\
\mathbf{R} \\
\mathrm{T}\end{array}$ & $\begin{array}{l}Y \\
Y \\
Y \\
Y\end{array}$ & This work \\
\hline CwlA, Cell wall hydrolase, Bacillus subtilis & 272 & $\begin{array}{r}83 \\
100\end{array}$ & $\mathrm{G}$ & $\begin{array}{l}\mathrm{TgN} \\
\mathrm{G} \mathrm{V}\end{array}$ & & $\begin{array}{l}\mathbf{K} \\
\mathbf{Y}\end{array}$ & Kuroda \& Sekiguchi (1990) \\
\hline$N$-Acetylmuramoyl-L-alanine amidase, Bacillus sp. & 251 & $\begin{array}{l}81 \\
98\end{array}$ & $\begin{array}{l}G \\
G\end{array}$ & $\begin{array}{l}\mathrm{RgN} \\
\mathrm{G} \mathrm{A}\end{array}$ & & $\begin{array}{l}\mathrm{H} \\
\mathrm{Y}\end{array}$ & Potvin et al. (1988) \\
\hline Cell wall hydrolase, Streptococcus faecalis & 667 & $\begin{array}{l}352 \\
419 \\
487 \\
555 \\
358 \\
426 \\
494 \\
562\end{array}$ & $\begin{array}{l}\mathrm{G} \\
\mathrm{G} \\
\mathrm{G} \\
\mathrm{G} \\
\mathrm{G} \\
\mathrm{G} \\
\mathrm{G} \\
\mathrm{G}\end{array}$ & $\begin{array}{ll}S & N \\
S & N \\
S & N \\
S & N \\
T & N \\
T & N \\
T & N \\
T & N\end{array}$ & $\begin{array}{l}N \\
N \\
N \\
N \\
T \\
T \\
T \\
T\end{array}$ & $\begin{array}{l}Q \\
N \\
N \\
N \\
Y \\
Y \\
Y \\
Y\end{array}$ & Béliveau et al. (1991) \\
\hline $\begin{array}{l}\text { LytA, } N \text {-acetylmuramoyl-L-alanine amidase, Staphylococcus } \\
\text { aureus }\end{array}$ & 481 & $\begin{array}{r}86 \\
197\end{array}$ & $\begin{array}{l}\mathrm{G} \\
\mathrm{G}\end{array}$ & $\begin{array}{ll}S & N \\
S & N\end{array}$ & & $\begin{array}{l}\mathrm{G} \\
\mathrm{K}\end{array}$ & Wang et al. (1991) \\
\hline $\begin{array}{l}\text { CPL-1, } N \text {-acetylmuramoyl-L-alanine amidase, bacteriophage } \\
\text { CP-1 }\end{array}$ & 342 & $\begin{array}{l}220 \\
268 \\
316\end{array}$ & $\begin{array}{l}\mathrm{G} \\
\mathrm{G} \\
\mathrm{G}\end{array}$ & $\begin{array}{ll}\mathrm{Q} & \mathrm{E} \\
\mathrm{Q} & \mathrm{E} \\
\mathrm{Q} & \mathrm{E}\end{array}$ & $\begin{array}{l}\mathbf{R} \\
\mathbf{R} \\
\mathbf{R}\end{array}$ & $\begin{array}{l}Y \\
Y \\
Y\end{array}$ & Garcia et al. (1990) \\
\hline $\begin{array}{l}\text { CPL-7, } N \text {-acetylmuramoyl-L-alanine amidase, bacteriophage } \\
\text { CP-7 }\end{array}$ & 339 & $\begin{array}{l}216 \\
268\end{array}$ & $\begin{array}{l}\mathrm{G} \\
\mathrm{G}\end{array}$ & $\begin{array}{ll}\text { S } & K \\
\text { S } & E\end{array}$ & $\begin{array}{l}\mathbf{P} \\
\mathbf{W}\end{array}$ & $\begin{array}{l}\mathrm{Y} \\
\mathbf{Y}\end{array}$ & Garcia et al. (1990) \\
\hline $\begin{array}{l}\text { CPL-9, } N \text {-acetylmuramoyl-L-alanine amidase, bacteriophage } \\
\text { CP-9 }\end{array}$ & 339 & $\begin{array}{l}216 \\
268\end{array}$ & $\begin{array}{l}G \\
G\end{array}$ & $\begin{array}{ll}S & K \\
S & E\end{array}$ & $\begin{array}{c}\mathrm{P} \\
\mathrm{W}\end{array}$ & $\begin{array}{l}\mathbf{Y} \\
\mathbf{Y}\end{array}$ & Garcia et al. (1990) \\
\hline Consensus motif & & & $\begin{array}{l}\mathbf{G} \\
28\end{array}$ & $\begin{array}{cc}\mathbf{S} & \mathbf{N} \\
15 & 16\end{array}$ & $\begin{array}{l}\mathbf{R} \\
13\end{array}$ & $\begin{array}{c}Y \\
20\end{array}$ & \\
\hline
\end{tabular}

higher than normal level. This leaves open the question of the universality of the model of Adhin \& van Duin (1989). However, a very strong promoter of the erythromycin resistance gene, from which $l y t C$ is expressed in the mutant investigated, could account for the translation of $l y t C$, even if the ribosomes have a small chance of staying attached in the long nontranslated intergenic region present in $l y t A^{-} B^{-} C^{+}$strains. The transcriptional control of lytR is mediated by two promoters, one of which, $P_{A, 2}$, has a good consensus to $\sigma^{A}$-controlled promoters while the other, $P_{X}$, a relatively strong one and located upstream of $P_{A, 2}$, exhibits at best a very poor homology to a $\mathrm{P}_{\mathrm{A}}$ consensus. LytR seems to be a selfattenuator since in a LytR-deficient strain expression 
from $P_{A, 2}$ is increased twofold while that formerly associated with $P_{X}$ is displaced, and apparently originates from at least three sites which are close to that present in the lyt $R^{+}$strain. Whether the latter phenomenon is due, at least in part, to the destabilization of mRNA remains to be investigated.

The global picture of the regulatory region of the lytRABC divergon, discussed above, allows a reassessment of the role of different mutants affecting the expression of the amidase. The effect of the flaA4 mutation (Pooley \& Karamata, 1984), which was shown to cause deficiency in the synthesis of the flagellum basal body (Albertini et al., 1991; Hauser et al., 1991) reveals the possibility of a feedback inhibition at the level of SigD synthesis. Indeed, reduction of about $70 \%$ of the amidase activity in a fla A4-bearing strain (H. M. Pooley, unpublished; S. Richard, unpublished) corresponds to absence of transcription of the lyt $A B C$ operon from $\mathrm{P}_{\mathrm{D}}$. Our observations shed hardly any light on the behaviour of mutants deficient at the level of the $\sin ($ flaD) gene (Sekiguchi et al., 1990), which was reported to encode a repressor (Gaur et al., 1991). Inactivation of $\sin$ by insertional mutagenesis leads again to a $70 \%$ decrease of the amidase activity, suggesting that the Sin protein is an effector of $\mathrm{P}_{\mathrm{D}}$. A possible explanation for the total absence of amidase activity in flaD2-bearing mutants, revealed by their inability to lyse cell walls contained in solid media, could be due to mutations provoking firm binding of the protein to an operator or to an effector with the result of blocking expression from $P_{D}$ and thus of the $\mathrm{P}_{\mathrm{A}}$ promoter located upstream. Absence of other $\sigma^{\mathrm{D}}$-controlled proteins (Mirel \& Chamberlin, 1989; P. Margot, unpublished) in flaD-bearing strains could mean that $S i n$ is an effector for all $P_{D}$ promoters which are inactivated in strains carrying flaD1 or flaD2 mutations. Finally, our observations provide a working hypothesis to explain the Ifm phenotype. Mutants with a two- to sevenfold higher amidase activity (H. M. Pooley, unpublished) owe their phenotype to at least two mutations localized in the chromosomal region encompassing the lytRABC divergon (Pooley \& Karamata, 1984). That the rate of the amidase expression in $l y t R$ bearing strains is increased four- to fivefold may not be sufficient to ensure a comparable increase at the CWBP49 level due to difficulties with protein export. Thus, the secondary mutation(s) in Ifm strains could affect one or more prs (Kontinen \& Sarvas, 1988) or other genes whose products are involved in protein export.

The partial integration of the lyt $A B C$ operon within the fla regulon is in agreement with a strongly impaired motility of lytC-deficient strains on semi-solid plates (Margot \& Karamata, 1992) and provides further support for the hypothesis (Fein \& Rogers, 1976; Pooley $\&$ Karamata, 1984) that the bulk of the amidase activity is required for the morphogenesis of the flagellum, in particular of its basal body. Finally, although comparison of the $P_{D}$ and SigD sequences with those controlling the flagellar motility regulons in E. coli and Salmonella typhimurium reveals a significant homology (Helmann \& Chamberlin, 1987; Helmann et al., 1988; Bartlett et al., 1988; Ohnishi et al., 1990), lyt genes of the latter organisms have not been shown to be integrated into the fla regulon.

We are grateful to Dr M. Chamberlin, University of Berkeley, for providing plasmid pLM5, and for communicating unpublished observations.

\section{References}

AdHIN, M. R. \& VAN DuIN, J. (1989). Translation regulation of the lysis gene in RNA bacteriophage fr requires a UUG initiation codon. Molecular and General Genetics 218, 137-142.

Albertini, A. M., Caramori, T., Crabb, W. D., Scoffone, F. \& GALIzzI, A. (1991). The flaA locus of Bacillus subtilis is part of a large operon coding for flagellar structures, motility functions, and an ATPase-like polypeptide. Journal of Bacteriology 173, 3573-3579.

Bartlett, D. H., Frantz, B. B. \& Matsumura, P. (1988). Flagellar transcriptional activators $\mathrm{FlbB}$ and FlaI: gene sequences and $5^{\prime}$ consensus sequences of operons under FlbB and FlaI control. Journal of Bacteriology 170, 1575-1581.

Béliveau, C., Potvin, C., Trudel, J., Asselin, A. \& Bellemare, G. (1991). Cloning, sequencing, and expression in Escherichia coli of a Streptococcus faecalis autolysin. Journal of Bacteriology 173 , 5619-5623.

Birchmeier, C., Birnbaum, D., Waitches, G., Fasano, O. \& Wigler, M. (1986). Characterization of an activated human ros gene. Molecular and Cellular Biology 6, 3109-3116.

Birnboim, H. C. \& DoLY, J. (1979). A rapid alkaline extraction procedure for screening recombinant plasmid DNA. Nucleic Acids Research 7, 1513-1523.

Bohannon, D. E. \& Sonenshein, A. L. (1989). Positive regulation of glutamate biosynthesis in Bacillus subtilis. Journal of Bacteriology 171, 4718-4727.

Brehm, J., Salmond, G. \& Minton, N. (1987). Sequence of the adenine methylase gene of the Streptococcus faecalis plasmid pAM $\beta 1$. Nucleic Acids Research 15, 3177.

Chambers, S. P., Prior, S. E., Barstow, D. A. \& Minton, N. P. (1988). The pMTL nic-cloning vectors. I. Improved pUC polylinker region to facilitate the use of sonicated DNA for nucleotide sequencing. Gene 68, 139-149.

Chung, C. T. \& Miller, R. H. (1988). A rapid and convenient method for the preparation and storage of competent bacterial cells. Nucleic Acids Research 16, 3580.

Del Sal, G., Manfioletti, G. \& Schneider, C. (1988). A one-tube plasmid DNA mini-preparation suitable for sequencing. Nucleic Acids Research 16, 9878.

DeVereuX, J., Haeberli, P. \& Smithies, O. (1984). A comprehensive set of sequence analysis programs for the VAX. Nucleic Acids Research 12, 387-395.

FeIN, J. E. \& Rogers, H. J. (1976). Autolytic enzyme-deficient mutants of Bacillus subtilis 168. Journal of Bacteriology 127, 1427-1442.

Ferrari, F. A., Nguyen, A., Lang, D. \& Hoch, J. A. (1983). Construction and properties of an integrable plasmid for Bacillus subtilis. Journal of Bacteriology 154, 1513-1515.

FosTER, S. (1991). Cloning, expression, sequence analysis and biochemical characterisation of an autolytic amidase of Bacillus subtilis 168 trpC2. Journal of General Microbiology 137, 1987-1998. 
Freier, S. M., Kierzek, R., JAEGer, J. A., SUgimoto, N., Caruthers, M. H., NeILSON, T. \& TURNER, D. H. (1986). Improved free-energy parameters for predictions of RNA duplex stability. Proceedings of the National Academy of Sciences of the United States of America 83, 9373-9377.

Garcia, P., Garcia, J. L., Garcia, E., Sanchez-Puelles, J. M. \& LOPEZ, R. (1990). Modular organization of the lytic enzymes of Streptococcus pneumoniae and its bacteriophages. Gene 86, 81-88.

GAUR, N. K., OPPENHEIM, J. \& SMITH, I. (1991). The Bacillus subtilis sin gene, a regulator of alternate developmental process, codes for a DNA-binding protein. Journal of Bacteriology 173, 678-686.

Gilman, M. Z. \& Chamberlin, M. J. (1983). Developmental and genetic regulation of Bacillus subtilis genes transcribed by $\sigma^{28}$-RNA polymerase. Cell 35, 285-293.

Gilman, M. Z., Wiggs, J. L. \& Chamberlin, M. J. (1981). Nucleotide sequences of two Bacillus subtilis promoters used by Bacillus subtilis sigma-28 R NA polymerase. Nucleic Acids Research 9, 5991-6000.

Gilman, M. Z., GlenN, J. S., Singer, V. L. \& Chamberlin, M. J. (1984). Isolation of sigma-28-specific promoters from Bacillus subtilis DNA. Gene 32, 11-20.

GrossBERgER, D. (1987). Minipreps of DNA from bacteriophage lambda. Nucleic Acids Research 15, 6737.

HarRison, S. C. \& AGgarwal, A. K. (1990). DNA recognition by proteins with the helix-turn-helix motif. Annual Review of Biochemistry 59, 933-969.

Hauser, P. M., Crabb, W. D., Fiora, M. G., Scoffone, F. \& Galizzi, A. (1991). Genetic analysis of the flaA locus of Bacillus subtilis. Journal of Bacteriology 173, 3580-3583.

HeERY, D. M., GanNon, F. \& Powell, R. (1990). A simple method for subcloning DNA fragments from gel slices. Trends in Genetics 6, 173.

vON HEIJNE, G. (1986). A new method for predicting signal sequence cleavage sites. Nucleic Acids Research 12, 4683-4690.

Helmann, J. D. \& Chamberlin, M. J. (1987). DNA sequence analysis suggests that expression of flagellar and chemotaxis genes in Escherichia coli and Salmonella typhimurium is controlled by an alternative $\sigma$ factor. Proceedings of the National Academy of Sciences of the United States of America 84, 6422-6424.

Helmann, J. D., Marquez, L. M. \& Chamberlin, M. J. (1988) Cloning, sequencing, and disruption of the Bacillus subtilis $\sigma^{28}$ gene. Journal of Bacteriology 170, 1568-1574.

HERBOLD, D. R. \& GlaSER, L. (1975). Bacillus subtilis $N$-acetylmuramic acid L-alanine amidase. Journal of Biological Chemistry 250, 1676-1682.

Illing, N. \& ERrington. J. (1991). Genetic regulation of morphogenesis in Bacillus subtilis: roles of $\sigma^{\mathrm{F}}$ and $\sigma^{\mathrm{F}}$ in prespore engulfment. Journal of Bacteriology 173, 3159-3169.

Jones, K. A., Yamamoto, K. R. \& TJian, R. (1985). Two distinct transcription factors binc to the HSV thymidine kinase promoter in vitro. Cell 42, 559-572.

K ARAMATA, D. \& Gross, J. D. (1970). Isolation and genetic analysis of temperature-sensitive mutants of Bacillus subtilis 168. Molecular and General Genetics 207, 73-81.

Kontinen, V. P. \& SARvas, M. (1988). Mutants of Bacillus subtitis defective in protein export. Journal of General Microbiology 134, 2333-2344.

Kontinen, V. P., Saris, P. \& Sarvas, M. (1991). A gene (prsa) of Bacillus subtilis involved in a novel, late stage of protein export. Molecular Microbiology 5, 1273-1283.

Krupinski, J., Coussen, F., Bakalyar, H. A., Tang, W.-J., Feinstein, P. G., Orth, K., Slaughter, C., Reed, R. R. \& Gilman, A. G. (1989). Adenylyl cyclase amino acid sequence: possible channel- or transporter-like structure. Science 244, 1558-1564.

K URODA, A. \& SeKiguchI, J. (1990). Cloning, sequencing and genetic mapping of a Bacillus subtilis cell wall hydrolase gene. Journal of General Microbiology 136, 2209-2216.

KURODA, A. \& SEKIGUCHI, J. (1991). Molecular cloning and sequencing of a major Bacillus subtilis autolysin gene. Journal of Bacteriology 173, 7304-7312.

LAEMMLI, U. K. (1970). Cleavage of structural proteins during the assembly of the head of bacteriophage T4. Nature, London, 227 , 680-685.

Lopez-Diaz, I., Clarke, S. \& Mandelstam, J. (1986). spoIID operon of Bacillus subtilis, cloning and sequence. Journal of General Microiology 132, 341-354.

MARGOT, P. \& KARAMATA, D. (1992). Identification of the structural genes for $\mathrm{N}$-acetylmuramoyl-L-alanine amidase and its modifier in Bacillus subtilis 168: inactivation of these genes by insertional mutagenesis has no effect on growth or cell separation. Molecular and General Genetics 232, 359-366.

Margot, P., Roten, C.-A. \& Karamata, D. (1991). N-Acetylmuramoyl-L-alanine amidase assay based on specific radioactive labeling of muropeptide L-alanine: quantitation of the enzyme activity in the autolysin deficient Bacillus subtilis 168 , flaD strain. Analytical Biochemistry 198, 15-18.

Marquez, L. M., Helmann, J. D., Ferrari, E., Parker, H. M., Ordal, G. W. \& Chamberlin, M. J. (1990). Studies of $\sigma^{\text {D}}$-dependent functions in Bacillus subtilis. Journal of Bacteriology 172, 3435-3443.

Mauël, C., Young, M., Margot, P. \& Karamata, D. (1989). The essential nature of teichoic acids in Bacillus subtilis as revealed by insertional mutagenesis. Molecular and General Genetics 215, 388-394.

Mirel, D. B. \& Chamberlin, M. J. (1989). The Bacillus subtilis flagellin gene (hag) is transcribed by the $\sigma^{28}$ form of RNA polymerase Journal of Bacteriology 171, 3095-3101.

OHNishi, K., Kutsukake, K., Suzuki, H. \& Iino, T. (1990). Gene flia encodes an alternative sigma factor specific for flagellar operons in Salmonella typhimurium. Molecular and General Genetics 221, 139-147.

Petersen, C. (1989). Long-range translational coupling in the rplJLrpoBC operon of Escherichia coli. Journal of Molecular Biology 206, 323-332.

PoOley, H. M. (1976). Turnover and spreading of old wall during surface growth of Bacillus subtilis. Journal of Bacteriology 125, $1127-1138$.

Pooley, H. M. \& Karamata, D. (1983). Correlation of cell wall turnover and autolytic activity in $f^{-}$and supermotile mutants of Bacillus subtilis. In Target of Penicillin, pp. 279-284. Berlin: Walter De Gruyter

Pooley, H. M. \& Karamata, D. (1984). Genetic analysis of autolysindeficient and flagellaless mutants of Bacillus subtilis. Journal of Bacteriology 160, 1123-1129.

Potvin, C., Leclerc, D., Tremblay, G., Asselin, A. \& Bellemare, G. (1988) Cloning, sequencing and expression of a Bacillus bacteriolytic enzyme in Escherichia coli. Molecular and General Genetics 214, 241-248

REED, K. C. \& MANN, D. A. (1985). Rapid transfer of DNA from agarose gels to nylon membranes. Nucleic Acids Research 13, 7207-7221.

Rogers, H. J., Perkins, H. R. \& Ward, J. B. (1980). Microbial Cell Walls and Membranes. London: Chapman \& Hall

ROgers, H. J., TAYLOR, C., RaYter, S. \& WARD, J. B. (1984) Purification and properties of autolytic endo- $\beta$ - $N$-acetylglucosaminidase and the $N$-acetylmuramyl-L-alanine amidase from Bacillus subtilis strain 168. Journal of General Microbiology 130 , 2395-2402.

Sambrook, J., Fritsch, E. F. \& Maniatis, T. (1989). Molecular Cloning: a Laboratory Manual, 2nd edn. Cold Spring Harbor, New York: Cold Spring Harbor Laboratory.

SANGER, F., Nicklen, S. \& Coulson, A. R. (1977). DNA sequencing with chain-terminating inhibitors. Proceedings of the National Academy of Sciences of the United States of America 74, 54635467.

Sekiguchi, J., Ohsu, H., Kuroda, A., Moriyama, H. \& Akamatsu, T (1990). Nucleotide sequence of the Bacillus subtilis flaD locus and a $B$. licheniformis homologue affecting the autolysin level and flagellation. Journal of General Microbiology 136, 1223-1230.

SharP, P. M. \& LI, W.-H. (1987). The codon adaptation index - a measure of directional synonymous codon usage bias, and its potential applications. Nucleic Acids Research 15, 1281-1295.

Sharp, P. M., Higgins, D. G., Shields, D. C., Devine, K. M. \& Hoch, J. A. (1990). Bacillus subtilis gene sequences. In Genetics and Biotechnology of Bacilli, vol. 3, pp. 89-98. Edited by M. M Zukowski, A. T. Ganesan \& J. A. Hoch. San Diego: Academic Press. 
ShieldS, D. C. \& SharP, P. M. (1987). Synonymous codon usage in Bacillus subtilis reflects both translational selection and mutational biases. Nucleic Acids Research 15, 8023-8040.

SINGER, V. L. (1987). Characterisation of promoters and genes controlled by Bacillus subtilis sigma 28 RNA polymerase. $\mathrm{PhD}$ thesis, University of California, Berkeley.

SOUTHERN, E. M. (1975). Detection of specific sequences among DNA fragments separated by gel electrophoresis. Journal of Molecular Biology 98, 503-517.

STUDER, R. E. (1988). Caractérisation de la paroi native de Bacillus subtilis et étude des protéines qui lui sont associées. $\mathrm{PhD}$ thesis, University of Lausanne.

Studer, R. E. \& Karamata, D. (1988). Cell wall proteins in Bacillus subtilis. In Antibiotic Inhibition of Bacterial Cell Surface Assembly and Function, pp. 146-150. Edited by P. Actor. Washington: American Society for Microbiology.

Tinoco, I., BoreR, P. N., Dengler, B., LeVine, M. D., Uhlenbeck,
O. C., Crothers, D. M. \& Gralla, J. (1973). Improved estimation of secondary structure in ribonucleic acids. Nature New Biology 246, 40-41.

Tullis, R. H. \& RuBin, H. (1980). Calcium protects DNase I from proteinase $\mathrm{K}$ : a new method for the removal of contaminating RNase from DNase I. Analytical Biochemistry 107, 260-264.

Wang, X., Wilkinson, B. J. \& Jayaswal, R. K. (1991). Sequence analysis of a Staphylococcus aureus gene encoding a peptidoglycan hydrolase activity. Gene 102, 105-109.

Ward, J. B., Curtis, C. A. M., Taylor, C. \& Buxton, R. S. (1982). Purification and characterisation of two phage PBSX-induced lytic enzymes of Bacillus subtilis 168: an $N$-acetylmuramoyl-L-alanine amidase and an $\mathrm{N}$-acetylmuramidase. Journal of General Microbiology 128, 1171-1178.

Yamaguchi, K., Yu, F. \& INOUYE, M. (1988). A single amino acid determinant of the membrane localization of lipoproteins in $E$. coli. Cell 53, 423-432. 